\title{
Indonesian Stock's Influencer Phenomenon: Did Financial Literacy on Millennial Age Reduce Herding Behavior?
}

\author{
Ananda Chairunnisa ${ }^{1}$, Zuliani Dalimunthe ${ }^{\left.2^{*}\right)}$ \\ 1,2 Management Department, Faculty of Economics and Business, Universitas Indonesia, Indonesia, \\ Kampus Baru UI, Depok 16424 \\ *Corresponding author; Email:zuliani_d@ui.ac.id
}

\begin{abstract}
In Indonesia's capital market, there was a phenomenon that famous influencers seem to lead to behavioral bias in the stock market. The stock price changed significantly after those stock influencers shared information or recommended certain stocks. This research examined how the stock influencer's credibility affected investors' investment in recommended stock. We collected data from 132 individual investors who participated in the research. We used a questionnaire with a 5-Likert scale. The result showed that an influencer's credibility had a significant influence on investors' herding behavior. However, there was no significant evidence that financial literacy matters in that relationship. Interestingly, we found there was no significant difference in herding behavior between millennial and non-millennial investors.
\end{abstract}

Keywords: Stock market influencers; herding behavior; financial literacy; millennial generation; Indonesia.

\section{INTRODUCTION}

Stock influencer was a new phenomenon that comes up in the stock exchange market. Some cases showed how a stock price moved significantly after an influencer recommends it or shared positive information regarding the stock on their social media. Elon Musk- the CEO of Tesla, who had more than 49 million followers- often posted on his Twitter information on where he made investments. Musk's tweets could influence the public, as shown on the stock's price following his tweets. For example, Tesla's stock price fell by $7 \%$ after Musk announced he took Tesla private [1]. Also, Shopify's stock price rose after Musk said it was "great" [15]. In another case, when Elon Musk posted "I kinda love Etsy," Etsy's stock price rose nearly 10\% [16].

A similar phenomenon occurred in the Indonesian stock exchange. The price of WIKA increased by $6.94 \%$ on November 27th, 2020, after being recommended by Yusuf Mansyur. Yusuf Mansyur was a religious leader with 2.8 million followers on his Instagram. Likewise, PGAS stock price increased by $4.37 \%$ on December 15th, 2020, after Kaesang Pangarep tweeted it as a good stock to buy. Kaesang Pangarep was a YouTuber with 2.2 million followers on his Twitter and the son of Indonesia's President. Recently, the price of MCAS also increased by $8.33 \%$ on January 5, 2021, after Raffi Ahmad stated that he got almost 30\% return from investing in the stock for two weeks investment period. Raffi Ahmad was a celebrity with 51 million followers on his Instagram. In Indonesia, a stock influencer came in the form of celebrities, public figures, or even religious leaders.

The stock influencers usually shared information or signal for stock recommendations through social media like Twitter and Instagram. The price of a stock often looked abnormal when an influencer tweeted or recommended the stock. This phenomenon indicated how their followers made transactions based on those tweets or recommendations. It raised the question of whether there was a herding behavior phenomenon in the capital market, especially in Indonesia. Herding behavior was a form of behavioral bias arising from irrational decision-making. A further question was what qualities those influencers possessed that lead investors to make investment decisions irrationally. As [25] mentioned, social influence caused a herding behavior where a person was easily influenced by the words of others when it represented a quarter of the majority. [24] stated that stock influencers in market share led to heuristic bias because investors preferred to minimize the risk in an uncertain condition.

[12] defined an influencer as one who influenced others in making a decision. An influencer usually had massive followers on their social media. Influencers or celebrities would influence people to accept messages they conveyed or to buy a product they endorsed. Thus, there was the celebrity endorsers concept. Similar to the role of a celebrity endorser, a stock influencers' action to recommend a stock created behavioral biases among his followers. The influencers made statements that were 
persuasive enough to determine their follower's intention to invest. For some followers (investors), imitating influencers' decisions gave them confidence and optimism in their investing [19].

[14] stated that celebrities had special features such a personal magnetism, lifestyle standard, or special skills to influence people. [10] stated that the credibility of a celebrity was a crucial factor discussed regarding celebrity endorsements. From 2,158 literature on celebrity endorsement issues, [10] found that about $17.79 \%$ of that literature discussed celebrity credibility. After examining the source-credibility theory developed by [10], [11] stated two crucial dimensions of source credibility, trustworthiness, and communication skills. Previously, [20] stated that a celebrity's credibility was explained through the credibility model that consists of trustworthiness, expertise, and attractiveness.

Most investors followed broker or peers' advice who had investment experience with a higher return. Herding behavior was a condition where an individual imitated the group's behavior or decision [7]. When investors applied herding behavior, they denied their confidence and existing information [23]. However, another argument stated that herding behavior could happen when investors did not have specific knowledge of the stock they choose. An investor who followed another's investor decision confessed that they did not have knowledge and confidence in the investment they chose. However, these investors did not want to lose the return opportunity, thus following the other investors [6]. Investors followed the herd because they were not ready to lose their money but want to be as good as their peers. Also, the investors were not confident enough to choose a stock [28].

Previous research showed that financial literacy was an essential variable for investment decisions [4]. Financial literacy was a guidance that gives investor confidence to make investment decisions. An investor with low financial literacy tended to make more emotion-based and less rational investment decisions [9], [26]. The research conducted by [23] showed that financial literacy could diminish behavioral bias in an investment decision. Financial literacy raised investors' confidence and ability to analyze a stock to make a rational decision. When investors had a good level of financial literacy, their behavioral biases diminished.

This research aimed to analyze how the relationship between stock influencers' credibility on the investor's herding behavior and examined the role of financial literacy as a moderating variable. This research conducted a survey and used a questionnaire to generate primary data.
Specifically, this research aimed at millennial investors because the millennial generation was a crucial population group in Indonesia. The millennial generation was productive and strongly attached to social media. The questionnaire consisted of four parts: investor background, the credibility of stock influencers, herding behavior, and financial literacy.

\section{Rational vs Irrational Investor decision- making}

Daniel Bernoulli introduced the Expected Utility Theory. The theory explained that investors behave rationally based on the expected value of investment alternatives and relate it with the investment risk. The theory stated that investors considered the expected value and the risk; thus, the outcome would be balanced [6]. The expected theory focused on maximum utility because everyone has different expected values. In contrast, the prospect theory introduced by [13] explained that every investor had a different reaction to risk. The prospect theory stated that investor psychology determined investment decisions because an investor did not always behave rationally under uncertainty. Behavioral bias led investor to make irrational decision [6].

Previous research had shown that irrational decisions occur due to incomplete market information [24]. One type of investor's irrational decisionmaking was herding behavior. [8] defined herding behavior as individuals collaborating without a centralized direction. In the capital market context, [27] stated that a jump increase in stock return should be considered as the result of herding behavior.

\section{Influencer's Credibility}

The credibility of a celebrity was a crucial factor in influencing people. Influences were easier to accept when the influencers had better credibility [3]. Credible and trusted influencers gave more substantial influence upon their followers to buy recommended products. An influencer with higher credibility would more significantly influenced their followers to imitate their investment decisions. An influencer with trusted recommendations and experience recommended products was reliable [17].

[25] mentioned that social influence caused the herding behavior, where a person was easily influenced by the words of others when they represented a quarter of the majority.

Following the influencers gave confidence to the investor on investment. The investor wanted to 
reach a higher return with minimum risk, so herding behavior was a shortcut for a good investment. This phenomenon could lead to behavioral biases because investors' decisions were only based on the influencers. Thus, based on previous research, in this study the researcher hypothesized that: H1: Influencer's credibility effect to investors herding behavior

An influencer's credibility was explained through the credibility model that consisted of trustworthiness, expertise, and attractiveness [20]. This model measured the effectiveness of influencers in influencing their followers. [10] stated two crucial dimensions of source credibility, trustworthiness, and communication skills. Trustworthiness and expertise were two elements that significantly influenced purchase decisions. Regarding the followers, experience was also the credibility that decided whether the followers will follow the influencer's decision.

\section{Herding Behavior among Millennial Age}

In 2020, the millennial group (25 to 34 years old) dominated social media users, followed by 18 to 24 years old, 55 - 64 years old, and lastly, over 64 years old. From here, we can see that the millennial group was closer to social media. As the dominant group who used social media, it made the millennial to be more straightforwardly influenced by an influencer in their investment activities.

H2: There were differences in herding behavior between millennial investors and nonmillennial investor

\section{The Moderating Role of Financial Literacy}

Financial literacy was the ability to manage financial resources effectively [5], [9]. [21] explained that good financial literacy gave significant differences in financial behavior. Financial literacy helped investors to deny irrelevant information [23], gave an investor the ability to analyze in choosing the financial product [4] and isolated investors from herding behavior [2]. Low levels of financial literacy caused behavioral bias because the decision was influenced more by psychology than by knowledge [18]. An investor committed to herding behavior was usually an investor with low financial literacy because they had low confidence in their investments [19]. Based on previous research, the researcher hypothesized that higher credibility of influencers could lead to more herding behavior, but the influence would diminish upon investors with high financial literacy:

H3: Financial literacy moderated the relationship between influencer's credibility and herding behavior

\section{RESEARCH METHOD}

\section{Research Model}

This study aimed to evaluate whether influencer credibility affected the herding behavior of investors in the capital market, and to evaluate whether financial literacy moderated this relationship. Specifically, this study also evaluated whether there were differences in the herding behavior between millennial and non-millennial generations. The research model was presented in Figure 1.

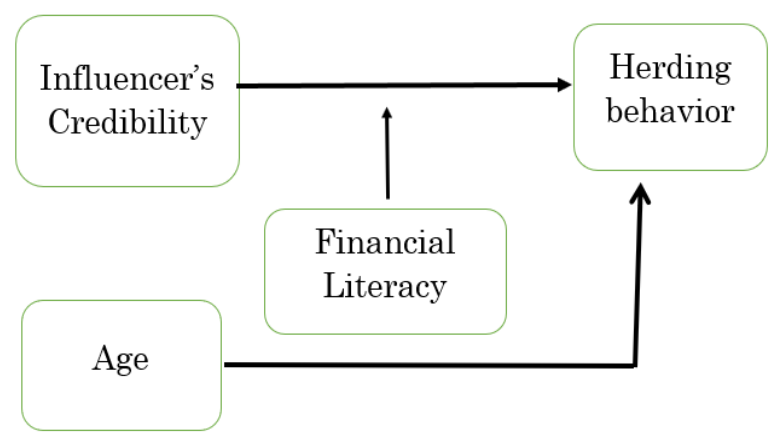

Figure 1. Research Model

\section{Sample and Data Collection}

This research was conducted using the quantitative method. Primary data used in this research had been collected by distributing the questionnaire online using Google Form. This research's target was individual investors who invest money in stock through the Indonesia's Stock Exchange. The questionnaire consisted of 32 items of questions and was divided into four parts. There were 156 respondents who participated in this research, 132 respondents of which were individual investors who invested through the Indonesia's Stock Exchange. The researcher analyzed the data using regression analysis by SPSS Software.

\section{Questionnaire Instrument}

The first part of the questionnaire consisted of questions on the respondent's background, covering gender, age, income, education, and investment experience. The second part was the stock influencer-credibility question, consisting of 8 questions adapted from [20]. The third part was the herding behavior concept, consisting of 9 questions adapted from [6] and [22]. For stock influencers' credibility and herding behavior questions, the answer used a Likert scale from 1 to 5 where one meant strongly disagree, and five meant strongly agree. The last part was related to financial literacy, a mini quiz, so the respondent chooses the best answer based on the given statement. The financial literacy question in the fourth part was developed from [18]. 


\section{RESULTS AND DISCUSSION}

\section{Results}

We collected the data from the 156 respondents who were participating. Out of them, 132 respondents made investments in the Indonesia Stock Exchange. Based on table 1, the majority of the respondent in this research were males at $65 \%$ and females at $35 \%$. The education level of respondents was dominated by bachelor degrees (79\%). 54\% of respondents were still actively investing in Indonesia Stock Exchange, 28\% of respondents rarely invested, and $9 \%$ were no longer active in the Indonesia Stock Exchange.

Table 1. Background of Respondents

\begin{tabular}{|c|c|c|}
\hline Items & Frequency & In Percentage (\%) \\
\hline \multicolumn{3}{|c|}{ 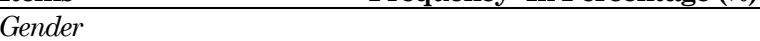 } \\
\hline Male & 86 & $65 \%$ \\
\hline Female & 46 & $35 \%$ \\
\hline \multicolumn{3}{|l|}{ Domicile } \\
\hline Greater Jakarta & 110 & $83 \%$ \\
\hline Java Island & 16 & $12 \%$ \\
\hline Other Java Island & 6 & $5 \%$ \\
\hline \multicolumn{3}{|l|}{ Age } \\
\hline$<25$ years old & 12 & $9 \%$ \\
\hline $25-40$ years old & 109 & $83 \%$ \\
\hline $41-56$ years old & 10 & $8 \%$ \\
\hline$>56$ years old & 1 & $1 \%$ \\
\hline \multicolumn{3}{|l|}{ Education Level } \\
\hline Senior High School & 4 & $3 \%$ \\
\hline Diploma/bachelor's degree & 104 & $79 \%$ \\
\hline Master's degree & 24 & $18 \%$ \\
\hline \multicolumn{3}{|l|}{ Income per Month } \\
\hline Until IDR 4 million & 9 & $7 \%$ \\
\hline IDR 4-10 million & 46 & $35 \%$ \\
\hline IDR 10 - 35 million & 72 & $55 \%$ \\
\hline IDR 35 - 100 million & 4 & $3 \%$ \\
\hline$>100$ million & 1 & $1 \%$ \\
\hline \multicolumn{3}{|l|}{ Investment Experience } \\
\hline Still actively investing in share & 71 & $54 \%$ \\
\hline Rarely investing in share & 37 & $28 \%$ \\
\hline Not actively investing in share & 12 & $9 \%$ \\
\hline Have invested in share & 12 & $9 \%$ \\
\hline
\end{tabular}

Based on the influencer credibility measurement in table $1,58 \%$ of respondents knew someone who was mentioned as stock influencers in this research. However, most respondents admitted that the stock influencers were not experts and experienced in investment activity. Surprisingly, $44 \%$ of respondents were found to be indicated with herding behavior in choosing their investments. The respondents considered the stock recommended by influencers. However, the survey showed that only $33 \%$ of respondents had intentions to invest in the influencers-recommended stocks because, from the financial literacy measurements, it was found that most respondents (91\%) had a high level of financial literacy. Most of the respondents scored in the range of 5 to 7 in answering mini-quizzes of financial literacy.
The questionnaire tested for the validity and reliability of each component. The results showed that the questionnaire was valid and reliable. The test result met the minimum requirements where the value of $r$ of each component was higher than 0.1697 or $\mathrm{r}$ value minimum to be said as valid. For the reliability test, the result showed that the questionnaire was reliable because the value of Cronbach's Alpha was higher than 0.5000. The detail of the result of the validity and reliability test were shown in Table 2 .

Table 2. Validity and Reliability Test

\begin{tabular}{|c|c|c|c|}
\hline & $R$-value & $\begin{array}{c}\text { Cronbach } \\
\text { alpha }\end{array}$ & results \\
\hline Influencer's Credibility & & 0.837 & \\
\hline $\begin{array}{l}\text { I know the names } \\
\text { mentioned as a stock } \\
\text { influencer }\end{array}$ & 0.342 & & valid \\
\hline $\begin{array}{l}\text { In my opinion, Stock } \\
\text { Influencer believes that } \\
\text { the recommended stock } \\
\text { has a reasonable } \\
\text { prospect. }\end{array}$ & 0.663 & & valid \\
\hline $\begin{array}{l}\text { In my opinion, stock } \\
\text { influencers are people } \\
\text { who are experts in stock } \\
\text { investing activities. }\end{array}$ & 0.81 & & valid \\
\hline $\begin{array}{l}\text { In my opinion, stock } \\
\text { influencers are people } \\
\text { who are experienced in } \\
\text { stock investing } \\
\text { activities. }\end{array}$ & 0.782 & & valid \\
\hline $\begin{array}{l}\text { In my opinion, stock } \\
\text { influencers have the } \\
\text { knowledge and } \\
\text { understanding of } \\
\text { recommended stocks. }\end{array}$ & 0.807 & & valid \\
\hline $\begin{array}{l}\text { In my opinion, stock } \\
\text { influencers are } \\
\text { dependable when } \\
\text { recommended a stock. }\end{array}$ & 0.735 & & valid \\
\hline $\begin{array}{l}\text { Stocks recommended by } \\
\text { stock influencers have } \\
\text { good performance. }\end{array}$ & 0.775 & & valid \\
\hline $\begin{array}{l}\text { In my opinion, stock } \\
\text { influencers have } \\
\text { essential information } \\
\text { that the public does not } \\
\text { have }\end{array}$ & 0.576 & & valid \\
\hline Herding Behavior & & 0.836 & \\
\hline $\begin{array}{l}\text { In my opinion, stock } \\
\text { influencers are } \\
\text { important as a source of } \\
\text { investment information. }\end{array}$ & 0.662 & & valid \\
\hline $\begin{array}{l}\text { I refer to influencer's } \\
\text { social media before } \\
\text { deciding to invest (buy } \\
\text { or sell) in stocks } \\
\text { recommended by } \\
\text { influencers. }\end{array}$ & 0.756 & & valid \\
\hline $\begin{array}{l}\text { I follow the broker's } \\
\text { advice before buy or sell } \\
\text { a stock. }\end{array}$ & 0.572 & & valid \\
\hline
\end{tabular}




\begin{tabular}{lccc}
\hline & R-value & $\begin{array}{c}\text { Cronbach } \\
\text { alpha }\end{array}$ & results \\
\hline $\begin{array}{l}\text { I follow influencer's social } \\
\text { media or forums before }\end{array}$ & 0.764 & & valid \\
investing. & & \\
I follow the stock price & 0.798 & valid \\
movement information & & \\
recommended by & & valid \\
influencers. & & \\
I know people who invest & 0.691 & \\
stock because & & \\
influencers recommend & & \\
them. & & \\
I know people who were & 0.573 & \\
disappointed by their & & \\
losses after buying stock & & \\
recommended by & & \\
influencers. & & \\
In my opinion, an & 0.508 & \\
investors' & & \\
disappointment & & \\
subsides when the & & \\
influencers experience & & \\
the same thing. & & \\
I do not want to fail to & 0.73 & \\
take advantage of the & & \\
chance of a price & & \\
increase on stocks & & \\
recommended by & & \\
influencers. & & \\
\hline
\end{tabular}

Table 3 showed the results of hypothesis testing from the regression run.

Table 3. Hypothesis Testing

\begin{tabular}{llccc}
\hline & Hypothesis & t-value & sig & results \\
\hline H1 & $\begin{array}{c}\text { Influencer's Credibility } \\
\text { towards Herding }\end{array}$ & 6.594 & 0.000 & Supported \\
Behavior & & & \\
H2 & $\begin{array}{c}\text { Age toward Herding } \\
\text { Behavior }\end{array}$ & -1.023 & 0.308 & $\begin{array}{c}\text { Not } \\
\text { supported }\end{array}$ \\
H3 & $\begin{array}{c}\text { Influencer's Credibility } \\
\text { towards Herding } \\
\text { Behavior with } \\
\text { Moderating Role of }\end{array}$ & 0.239 & 0.811 & $\begin{array}{c}\text { Not } \\
\text { Supported }\end{array}$ \\
& & & \\
\hline Financial Literacy & & & \\
\hline
\end{tabular}

The results of hypothesis testing shown in table 3 showed that the influencer's credibility had a significant positive influence on herding behavior, with a t-value of 6.594 and a p-value of 0.000 . Therefore, the chance for investors to do herding behavior increased along with the credibility of influencers who recommended the stocks. The booming stock influencer investing in the stock market seems to be followed by a significant number of investors who imitate their decisions.

Regarding the age towards herding behavior, the result showed that age negatively influenced herding behavior with a t-value -1.023, and the pvalue was over 0.05 or 0.308 . This result meant that there was not enough proof that there were differences between millennials and non-millennial in herding behavior.
The third hypothesis was regarding the moderating role of financial literacy. The regression showed a t-value of 0.239 and a p-value of 0.811 . This result meant that no significant proof that financial moderates the relationship between influencers' credibility and herding behavior was found. In summary, we concluded that $\mathrm{H} 1$ was accepted while $\mathrm{H} 2$ and $\mathrm{H} 3$ were rejected.

\section{Discussion}

This study results showed that an influencer's credibility significantly influenced investors' herding behavior. A higher level of credibility led to a higher level of herding behavior. Knowing that credible and trusted influencers recommended a stock led the investor to imitate the influencer on investing. This finding aligned with the research conclusions in marketing, which stated that celebrity credibility was positively related to the intention to purchase the recommended product. The findings in this study were interesting because the influence of celebrities or influencers on investment decisions was not common in the financial area. Financial studies were based on the assumption that investors will make rational investment decisions by balancing expected returns and risks. However, this finding proved the prospect theory by [13], who stated that investors tend to show behavior bias when deciding under uncertainty. The motivation of investors in mimicking was to be as successful as the influencers in investing. The investor chose to imitate influencers' decisions [19]. The investors wanted to take higher returns without losing money or having a higher risk, so herding behavior was a shortcut for them to invest [28]. Thus, the credibility of the influencer positively affected the investors' intention to invest.

This finding had both good and bad implications for the capital market. Indications that influencers could create imitation effects in investment decisions provided an opportunity for issuers to use influencers to move market prices. In this situation, the market price no longer reflected its fair value. Moreover, the higher the price distortion, the higher the risk of a sudden price correction. As a result, market volatility was high. This situation reflected the poor quality of the capital market because price movements were not due to information entering the market, but by herding behavior with poor information value instead. Regulators should take action to minimize price movements that did not reflect information.

The second question in this research was regarding the different investment behavior between the millennial and non-millennial age. Surprisingly, we found that there was no significant 
difference between millennial and non-millennial investors. It meant that herding behavior occurred in every age group. Nevertheless, this finding needed further research because several studies have found different investment behavior in different age groups. Moreover, as many as $83 \%$ of respondents in this research were millennials, which might create biased findings.

The third question in this research was about the moderating role of financial literacy. This study found that financial literacy did not moderate the relationship between influencer credibility and herding behavior. The result was consistent with the research [19], who found that financial literacy cannot moderate investor herding behavior. This result was quite different from [4], where financial literacy significantly affected investment decisions. However, this difference might be due to the context in which [4] discussed investment in crowdfunding, whereas this study discussed investment in general. In addition, both [4] and [19] found that financial literacy affected investment decisions directly, not as a moderating variable.

\section{CONCLUSION}

The research revealed that the existence of influencers on the stock market brought a herding behavior. Herding behavior here referred to investor decision-making that followed an influencer or celebrity recommendation or persuasion through social media. Herding behavior represented a bias from rationally based decision-making. Specifically, this study analyzed whether an influencer's credibility led to investor herding behavior in a capital market. The credibility model measured the effectiveness of influencers in influencing their followers. The result showed that there was a significant influence on the influencers' credibility to herding behavior. The higher the credibility of the influencer, the higher the herding behavior could be. Theoretically, herding behavior represented irrational decision-making. Thus, the behavior should diminish among investors with high financial literacy. However, this research did not conform to that hypothesis. We found that investor financial literacy did not moderate the herding behavior. We also found no significant difference between herding behavior among the millennial and non-millennial groups of respondents.

The researcher acknowledged that this study involved a limited number of respondents, only 132 respondents. In addition, this research focused on the credibility aspect of influencers, which was the respondent's perception. Despite the research finding showing a positive relationship between influencer credibility and herding behavior, the questionnaire in this study only asked respondents' perceptions of three influencers who did stock recommendations in Indonesia in the last few months. We cannot predict whether such stock recommendation phenomenon would be persistent in the long term or just impulsive. Nevertheless, regulators should prevent similar events from happening in the future because they caused market volatility with a lack of information value.

\section{REFERENCES}

[1] Adamczyk, A. (2018, December 11). Lifehacker. Retrieved from Lifehacker: https:/lifehacker. com/how-ceo-behavior-like-elon-musks-influences-stock-price-1831010286

[2] Adil, M., Singh, Y., \& Ansari, M. S. (2021). How financial literacy moderate the association between behaviour biases and investment decision? Asian Journal of Accounting Research, 1-17.

[3] AlFarraj, O., Alalwan, A. A., Obeidat, Z. M., Baabdullah, A., Aldmour, R., \& Al-Haddad, S. (2021). Examining the impact of influencers' credibility dimensions: attractiveness, trustworthiness and expertise on the purchase intention in the aesthetic dermatology industry. Review of International Business and Strategy, 1-20.

[4] Arifah, J. N., \& Dalimunthe, Z. (2020). The impact of financial literacy on the investment decision of non-donation-based crowdfunding in indonesia. International Journal of Business and Society, 21(3), 1045-1057.

[5] Ates, S., Coskun, A., Sahin, M. A., \& Demircan, M. L. (2016). Impact of financial literacy on the behavioral biases of individual stock investors: evidence from borsa istanbul. Business and Economics Research Journal, 7(3), 1-19.

[6] Baker, H. K., Kumar, S., Goyal, N., \& Gaur, V. (2019). How financial literacy and demographic variables relate to behavioral biases. Managerial Finance, 45(1), 124-146.

[7] Bobe, M. C., \& Piefke, M. (2019). Why do we herd in financial contexts? Journal of Neuroscience, Psychology, and Economics, 12(2), 116140.

[8] Choijil, E., Mendez, C. E., Wong, W. K., Vieito, J. P., \& Batmunkh, M. U. (2022). Thirty years of herd behavior in financial markets: a bibliometric analysis. Research in International Business and Finance, 59, 1-13.

[9] Disney, R., \& Gathergood, J. (2013). Financial literacy and consumer credit portfolios. Journal of Banking \& Finance, 37(7), 22462254.

[10] Halder, D., Pradhan, D., \& Chaudhuri, H. R. (2021). Forty-five years of celebrity credibility 
and endorsment literature: review and learning. Journal of Business Research, 125, 397415.

[11] Hovland, C. I., \& Weiss, W. (1951). The influence of source credibility on communication effectivness. Public Opinion Quarterly, 15, 635650.

[12] Kadekova, Z., \& Holiencinova, M. (2018). Influencer marketing as a modern phenomenon creating a new frontier of virtual opportunities. Communication Today, 9(2), 90-104.

[13] Kahneman, D., \& Tversky, A. (1979). Prospect theory: an analysis of decision under risk. Econometrica, 47(2), 263-292.

[14] Komala, K., \& Triono, R. A. (2020). Do a celebrity endorser and live broadcast sponsorship affect purchase intention in the case of PT Yamaha Indonesia Motor Manufacturing (YIMM)? Contemporary Issues in Finance, Accounting, and Consumers' Behavior: Lessons from Indonesia, 269-288.

[15] La Monica, P. R. (2021, January 26). Investing. Retrieved from CNN Business: https://edition. cnn.com/2021/01/26/investing/elon-musk-etsytwitter/index.html

[16] La Monica, P. R. (2021, February 17). Investing. Retrieved from CNN Business: https://edition.cnn.com/2021/02/17/investing/elon-musksocial-media/index.html

[17] Lim, X. J., Radzol, A. R., Cheah, J. H., \& Wong, M. W. (2017). The impact of social media influencers on purchase intention and the mediation effect of customer attitude. Asian Journal of Business Research, 7(2), 19-36.

[18] Mouna, A., \& Jarboui, A. (2015). A study on small investors' sentiment, financial literacy and stock returns: evidence for emerging market. International Journal of Accounting and Economics Studies, 3(1), 10-19.

[19] Novianggie, V., \& Asandimitra, N. (2019). The influence of behavioral bias, cognitive bias, and emotional bias on investment decision for college student with financial literacy as the moderating variable. International Journal of Academic Research in Accounting, Finance and Management Sciences, 9(2), 92-107.

[20] Ohanian, R. (1990). Construction and validation of a scale to measure celebrity endorsers' perceived expertise, trustworthiness, and attractiveness. Journal of Advertising, 19(3), 39-52.

[21] PACFL. (2008). 2008 annual report to the president. 4-9.

[22] Prosad, J. M., Kapoor, S., \& Sengupta, J. (2015). Behavioral biases of indian investors: a survey of delhi-ncr region. Qualitative Research in Financial Markets, 7(3), 230-263.

[23] Sabir, S. A., Mohammad, H. B., Kadir, H. B., \& Shahar. (2019). The role of overconfidence and past investment experience in herding behaviour with a moderating effect of financial literacy: evidence from pakistan stock exchange. Asian Economic and Financial Review, 9(4), 480-490.

[24] Shah, S.Z., Ahmad, M., \& Mahmood, F. (2018). Heuristic biases in investment decisionmaking and perceived market efficiency. Qualitative Research in Financial Markets, 10(1), 85-110.

[25] Susanto, S. A., \& Anastasia, N. (2019). Herding behavior and decision making within the middle-class residential property investment. Jurnal Akuntansi dan Keuangan, 21(2), 90100.

[26] Utami, E. S., Aprilia, M. R., \& Putra, I. C. (2021). Financial literacy of micro, small and medium entreprises of consumption sector in probolinggo city. Jurnal Manajemen dan Kewirausahaan, 23(1), 10-17.

[27] Wanidwaranan, P., \& Padungsaksawasdi, C. (2020). The effect of return jumps on herd behavior. Journal of Behavioral and Experimental Finance, 27, 1-11.

[28] Zhang, W. (2020). Application of crowd thought and herd behavior in economic investment. Revista Argentina de Clinica Psicologica, XXIX(1), 328-333. 